PROBLEMS

OF MANAGEMENT

IN THE $21^{\text {st }}$ CENTURY

volume 6, 2013

\title{
INTEGRATED TALENT MANAGEMENT - A CHALLENGE OR NECESSITY FOR PRESENT MANAGEMENT
}

\author{
Dana Egerová \\ University of West Bohemia, Czech Republic \\ E-mail: egerova@kpm.zcu.cz
}

The current highly competitive and unstable business environment, the requirements of the knowledge society and the development of new technologies is a reality which presents new challenges directed at various areas of the society, including human resources, to organizations and their management. It is becoming increasingly evident that the quality of human capital and practical implementation of human resources development are ones of the decisive factors of organizations' success and competitiveness and a key source that considerably determines the operation and economic performance of organizations.

The importance of the talent management concept for organizations is growing as a consequence of the ongoing globalization of the labour market and as a result of changes in the structure of labour force, particularly due to the aging and inadequate qualification structure of workforce on the one hand, and growing demands on the knowledge and skills of employees and the need for skilled labour on the other hand. Business practice but also studies carried out in the given area (CIPD, 2009, Deloitte, 2010) confirms that the talent management is becoming one of the main tools of business competitiveness. Above all, the organizations that are able to recruit, develop and retain existing but also future talents will gain a competitive advantage over the others. Talented employees are those who significantly contribute to the implementation of the strategy and objectives of an organization and thus to the success and prosperity of every organization.

The key questions in connection with the talent management concept are "Who is a talent?" and "What is talent?" The term talent in the organizational concept is used for highquality staff or employees who are vital for company performance. Talent is also understood as a source of competitive advantage. To approach and define talent in business practice, inclusive or exclusive approaches are used. An inclusive approach is based on the fact that every single person is perceived as a talent that contributes to the success of an organization and is a source of its competitive advantage. An exclusive approach then associates talent with only high performing individuals or high potential employees. It is necessary to realize that talent management in any organization is determined by the fact how such an organization defines the concept of talent and what approach it adopts. A clear definition of the talent concept that is accepted by all involved participants is the initial and absolutely essential step for successful talent management in every organization.

Talent management is a multi-faceted concept that is viewed differently in theory and practice. There are different definitions and different approaches to talent management in professional literature but also in organizations. Talent management can be understood as a philosophy of human resources management, as an organizational mindset, as a discipline with a specific subject and methods of research or as a set of HR policies, processes and programmes implemented in a particular organization. The concept of talent management in organizations often reflects their specific needs.

At present there is no uniform definition of the term. Lewis, Heckman (2006) defined the following three concepts of talent management definitions. Talent management as a set of personnel activities; talent management in this concept is, to a greater or lesser extent, perceived 
as a synonym for human resources management. Talent management coupled with the creation of databases of talents (talent pools) and talent management focused on the development of competencies through managing talents.

Generally, the definitions of talent management can be distinguished in terms of a broader or narrower concept. In the narrower sense, talent management is primarily focused on individual processes or sub-groups of employees. In the broader sense, talent management is viewed as a complex, integrated and holistic system that integrates all the components of talent management.

As mentioned above, present environment brings about a number of changes to which organizations must react adequately. It follows that management of organizations, inter alia, need to rethink approaches and strategies, which have previously been applied in various areas of organizational life, and select those that will enable them to cope with the new economic reality. For talent management, this means a shift from the traditional, often unsystematic approach to new approaches that can reflect the changed reality.

Most of the currently used processes of talent management were created almost half a century ago, and now the time has come to create a new model (Cappelli, 2008). According to a study conducted by Deloitte (2010), only 20\% of executives and specialists in human resources questioned said they had carefully worked-out talent management programmes; on the contrary, nearly $40 \%$ said that it was necessary to make partial or radical changes in those programmes. Most respondents also stated that due to the current economic situation it was necessary to rethink strategies for talent management. Particularly approaches that are mainly focused only on partial aspects of the given concept and do not sufficiently emphasize the integrated approach to talent management are currently applied in organizations as far as talent management is concerned. Talent management is not integrated in these organizations in any way or it is mainly used at the basic level provided that the traditional approaches and practices of talent management are applied within an organization. However, in this context it is necessary to realize that this concept may partially and temporarily suit its purpose, generally, however, this level of integration does not bring a real value to the organization. (Silzer, Dowell, 2010).

One of the new approaches is integrated talent management. Integrated talent management can be defined as an innovative and holistic approach to talent management, which enables an organization to adequately and flexibly respond to changes in the business environment. The concept of integrated talent management integrates the business strategy, the human resources strategy, talent management processes and organizational culture (Avedon, Scholes, p. 80 in Silzer, Dowell, 2010).

Integrating talent management with the strategy of an organization is one of the prerequisites of the effective talent management and the initial step in formulating the talent management strategy. The interconnection of the business strategy with the talent management strategy makes it possible to identify talent management processes that are crucial for achieving strategic objectives of an organization.

The talent management strategy needs to be also interconnected with the human resources strategy. It is necessary that various initiatives of talent management and HR activities, processes and systems are interconnected at least at the minimum level. However, it is most effective if they are fully integrated. The integration of the talent management strategy with the HR strategy can be carried out in different ways from the use of philosophy and principles that are the basis of human resources strategy through the use of various HR systems to the use of competency models.

Integration of talent management processes means that these processes do not run as independent and isolated processes, but as interconnected and related processes, when the output of one process is the input of the following one.

Integration with the organizational culture means that the values in talent management processes are consistent with the values of the organizational culture. A culture that supports processes and policies of talent management is the precondition for its successful integration. 
Dana EGEROVÁ. Integrated Talent Management - a Challenge or Necessity for Present Management

PROBLEMS

OF MANAGEMENT

IN THE $21^{\text {st }}$ CENTURY Volume 6, 2013

Another important condition for the talent management effectiveness is also the level of managers' engagement and support in creating talent strategies. What importance managers attach to talents as a strategic value for the organization also plays a significant role.

Integration at all the above-mentioned levels is a prerequisite and, at the same time, necessity for the successful implementation and application of the integrated talent management concept. From the procedural point of view, it means their interconnection, mutual support and reinforcement. It is necessary to realize that talent management strategies will vary, especially depending on the business strategy, the life cycle of a company, but also on the degree of engagement of company management. The organizational culture also plays an important role.

In conclusion, let us add that talent management is not only the HR processes and activities, but it is also a way of thinking and decision making, in which the holistic and integrated approaches are used in order to gain a real competitive advantage for an organization and its employees. Therefore, we should approach talent management as one of the key assets of organizations' competitiveness and also as one of their core values.

I believe that this current issue will bring you not only new and interesting findings, but also ideas and inspiration for your further professional activities.

\section{References}

Cappelli, P. (2008). Talent management for the twenty first century. Harvard Business Review, 86 (3), 74-81.

CIPD. The war on Talent? Talent management under threat in uncertain times. Part 1 (2009). Retrieved 28/02/2013, from http://www.cipd.co.uk/NR/rdonlyres/DFC760F8-F37C-4548-94705154073FE4EC/0/warontalent.pdf

Deloitte, Talent Edge 2020: Blueprints for the new normal. (2010). Retrieved 29/02/2013, from http:// www.Deloitte.com/us/talent

Egerová, D. (2012). Integrovaný talent management - nové paradigma pro talent management. Trendy $v$ podnikání, 2 (2), 8-13.

Lewis, R. E., \& Heckman, R. J. (2006). Talent Management: A critical review. Human Resource Management Review, 16 (2), 139-154.

Silzer, R., Dowell, B. E. (Eds). (2010). Strategy-Driven Talent Management. A Leadership Imperative. San Francisco: John Wiley \& Sons.

Received: March 05, 2013

Accepted: March 29, 2013

Dana Egerová

Ph.D., Assistant Professor, University of West Bohemia, Husova 11,306 14,

Pilsen, Czech Republic.

E-mail: egerova@kpm.zcu.cz

Website: http://fek.zcu.cz/osobni.php?IDWorker=77 